Pemetaan Lingkungan Korosi ...

\title{
PEMETAAN LINGKUNGAN KOROSI BAWAH PERMUKAAN MENGGUNAKAN METODE SELF-POTENSIAL BERDASARKAN NATIVE POTENTIAL PADA DAERAH UNIT 7 DAN 8 PT.IPMOMI
}

\author{
Masruro Amalia, Widya Utama, Juan Pandu Gya Nur Rochman \\ Teknik Geofisika, Fakultas Teknik Sipil dan perencanaan, Institut Teknologi Sepuluh Nopember \\ masruro.amalia@gmail.com
}

\begin{abstract}
Abstrak. Korosivitas tanah merupakan salah satu masalah yang berdampak pada kerusakan lingkungan dan infrastruktur. Pipa yang terletak pada subsurface menjadi salah satu contoh dari infrastruktur yang rentan terhadap korosi, maka dari itu pemetaan subsurface sangat dibutuhkan untuk mengetahui keadaan lingkungan korosif bawah permukaan. Pada tugas akhir ini dilakukan penelitian mengenai pemetaan lingkungan korosi bawah permukaan dengan menggunakan metode Self Potensial pada daerah unit 7 dan 8 PT.IPMOMI. Pengukuran self potensial dilakukan 2 kali yaitu pada awal penelitian dan 15 hari setelahnya. Dari hasil pengukuran SP kemudian dikorelasi dengan nilai native potensial sehingga didapat range nilai korosivitas tanah. Nilai SP -120 hingga 40 memiliki tingkat korosivitas sedang, dan nilai SP 40220 memiliki tingkat korosivitas yang sangat tinggi. Pada lokasi penelitian tingkat korosivitas yang sangat tinggi berada pada sisi utara dari lintasan dan semakin rendah pada sisi selatan yang disebabkan oleh adanya intrusi air laut pada sisi utara dari lokasi penelitian.
\end{abstract}

Kata kunci : Korosivitas tanah, intrusi, native potential, self-potential

\begin{abstract}
Soil corrosivity is one of the problems that impact on the environment and infrastructure damage. Pipes located at subsurface are one of a corrosion prone infrastructure, hence subsurface mapping is needed to determine the state of the subsurface corrosive environment. In this final project conducted research on mapping the environment of subsurface corrosion by using Self Potential method on unit 7 and 8 PT.IPMOMI. Self-potential measurements were made twice at the start of the study and 15 days afterwards. From result of $S P$ measurement then correlated with native potential value and as result range of soil corrosivity value is obtained. The values of SP-120 to 40 have moderate corrosivity, and SP 40-220 has a very high degree of corrosivity. At the research site, very high level of corosivity lies on the northern side of the track and lower on the southern side caused by the intrusion of sea water on the northern side of the research site.
\end{abstract}

Key Words : Soil corrosivity, intrusion, native potential, self potential.

\section{PENDAHULUAN}

Korosivitas tanah merupakan masalah yang memiliki dampak besar pada kinerja ekonomi dan lingkungan serta infrastruktur yang berbahan logam. Akibatnya, tingkat korosivitas tanah dianggap sebagai penghalang dalam pertumbuhan pembangunan mengingat banyaknya infrastruktur yang letaknya tertanam dibawah tanah, salah satunya yang banyak ditemui ialah pipa yang terletak dibawah permukaan (underground).

Pipa merupakan elemen penting dari suatu kesatuan industri seperti pada PT.IPMOMI yang 
bergerak dalam industri pembangkit listrik tenaga uap (PLTU). PT.IPMOMI memiliki banyak pipa yang letaknya berada dibawah permukaan tanah, pipapipa tersebut digunakan untuk mengalirkan air laut untuk proses produksi.

Kebanyakan kerusakan pipa yang berada dibawah permukaan tanah disebabkan oleh korosi. Untuk mencegah ataupun mengurangi korosi maka dilakukan proteksi pada pipa seperti dipasang coating dengan cat, aspal atau bahan lain yang bisa digunakan untuk perlindungan. Selain itu juga bisa digunakan pencegahan kerusakan pipa dengan mengontrol lingkungan penyebab korosi, maka dari itu diperlukan pemetaan lingkungan bawah permukaan, dalam kasus ini lingkungannya berupa tanah/soil.

Beberapa faktor penting yang dapat mempengaruhi laju korosi dari tanah atau peningkatan sifat korosifitas pada tanah antara lain air, pH tanah, derajat aerasi, resistivitas, potensial redoks dan aktivitas mikrobiologi. Dan pada penelitian kali ini akan dibahas mengenai factor korosifitas tanah yang berupa kandungan air dalam tanah/kelembaban dan penyebabnya.

Air, dalam bentuk larutan maupun gas merupakan syarat dasar untuk reaksi elektrokimia pada proses korosi, dimana tanah dibedakan menjadi dua daerah yaitu daerah saturated dan daerah unsaturated, dimana daerah itu mewakili pergerakan air dari daerah yang basah (saturated) ke daerah yang kering (unsaturated) dengan gaya gravitasi. Walaupun secara teori air selalu bergerak dari tampat yang tinggi menuju tempat yang rendah, namun di dalam tanah dapat terjadi sebaliknya. Air yang terdapat pada tanah basah yang berada di bawah dapat bergerak menuju tanah kering yang posisinya di atas tanah basah melalui gaya kapileritas.

Pada daerah saturated, aliran air bergantung pada besarnya pori-pori tanah dan penyebarannya, tekstur tanah, struktur tanah, dan kandungan unsur organik dalam tanah tersebut. Pergerakan air dari satu daerah ke daerah lainnya dapat terjadi melalui beberapa cara yaitu dengan gravitasi, gaya kapileritas, tekanan osmosis dan interaksi elektrostatik antar partikel tanah.

Air merupakan elektrolit yang memicu reaksi elektrokimia sehingga menyebabkan korosi. Perbedaan tersebut disebabkan oleh aliran air jenuh dan tidak jenuh pada tanah yang berhubungan dengan pergerakan air dari daerah yang basah menuju daerah yang kering. Kejenuhan air tergantung dari ukuran dan distribusi pori, tekstur, struktur, dan bahan organik.

Korosi pada tanah atau soil corrosion adalah jenis korosi aqueous dengan mekanisme elektrokimia. Namun kondisi pada tanah dapat menggeser atmosferik menjadi keadaan immersed tergantung dari kepadatan tanah dan kadar kristal air (moisture content). Walaupun mekanismenya merupakan elektrokimia, banyak karakteristik tanah yang akan meningkatkan korosifitas seperti hujan, iklim maupun reaksi pada tanah tersebut. Pada tanah, air dibutuhkan untuk ionisasi untuk oksidasi pada permukaan logam. Air juga dibutuhkan untuk ionisasi elektrolit tanah, untuk melengkapi sirkulasi aliran arus pada aktivitas korosi. Dengan demikian, air mempunyai pengaruh dalam terjadinya korosi pada tanah.

Kelembaban tanah sangat penting terhadap mekanisme korosi, contohnya tanah yang mengandung pasir kering akan lebih tahan korosi dibandingkan tanah yang mengandung tanah liat basah. Daerah dengan kelembaban yang tinggi dapat menyababkan nilai resistivitas suatu tanah akan menurun sehingga daerah tersebut memiliki tingkat korosi yang tinggi. Hal ini disebabkan uap air adalah salah satu pemicu atau media elektrolit dalam peristiwa korosi

Metode geofisika yang digunakan dalam pemetaan ini berupa metode geolistrik Selfpotential. Karena metode self-potential (SP) ini merupakan metode yang baru dikembangkan dalam bidang pemetaan lingkungan korosivitas tanah maka peneliti melakukan korelasi antara metode SP dengan metode Pipe to soil yang berupa native potential. 
Prinsip dasar dari metode SP ini ialah mengukur potensial alami batuan dengan menggunakan elektroda non poarisasi yang dihubungkan pada multimeter. Metode ini sangat efektif untuk survey geofisika dangkal dan sangat sensitif terhadap kandungan air dalam tanah. Tujuan dari penelitian ini ialah untuk mengetahui daerah yang memiliki tingkat korosivitas tanah yang tinggi beserta penyebabnya.

\section{METODOLOGI}

Alur pengerjaan penelitian dapat dilihat pada Gambar 1.

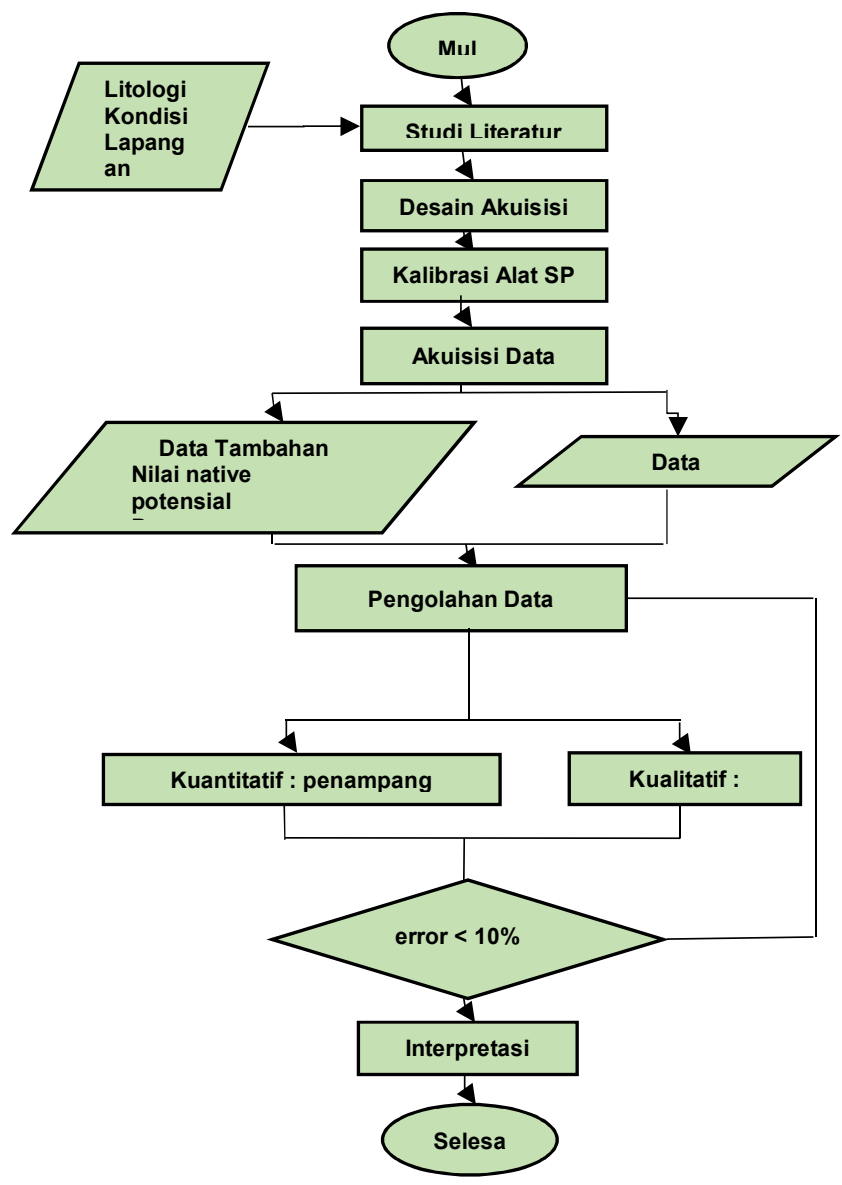

Gambar 1. Diagram Alir Penelitian.

Akuisisi data Self Potensial berada di unit 7 dan unit 8 yang berada dibawah kendali PT. IPMOMI pada lokasi PLTU Paiton, Kabupaten Probolinggo. Lintasan yang digunakan sebanyak 6 lintasan dengan jarak antar lintasan sebesar 3 meter dan panjang lintasan 1-5 sepanjang 75 meter sedangkan lintasan 6 memiliki panjang 33 meter. Berikut adalah peta daerah daerah penelitian :

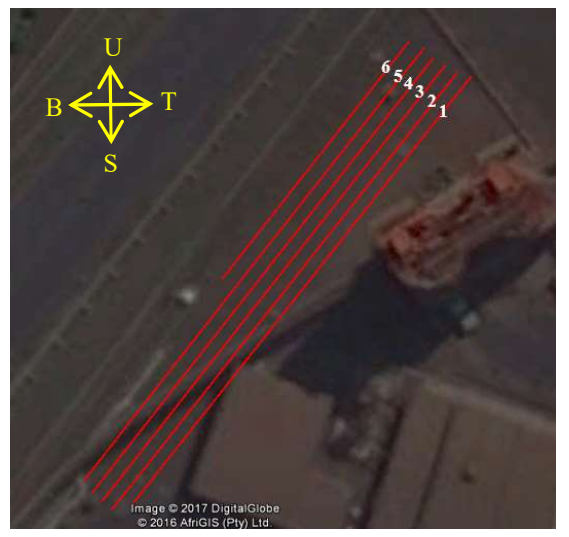

Gambar 2 Desain akuisisi pengukuran Self-Potential

Lokasi lintasan pengukuran berada dibawah fly ash Silo di system A unit 7 dan 8 PT.IPMOMI. elevasi daerah pengukuran berada pada 4.5 mdpl dan kedalaman pipa berada pada 3 meter dibawah permukaan tanah. Karena pipa telah terproteksi katodik maka pada saat pengukuran system proteksi dimatikan agar tidak mempengaruhi proses pengukuran. Tanah pada lokasi pengukuran berupa tanah urukan dengan elevasi 4.5 mdpl, yang diambil dari sisi selatan lokasi penelitian yaitu pada daerah pegunungan ringgit dan berupa kerikil sehingga cukup menyulitkan peneliti pada saat penanaman porouspot. Pada penelitian ini juga diambil data Native potential yang nantinya akan dikorelasikan dengan nilai Self potensial guna mendapatkan nilai korosivitas tanah.

Data self potensial yang telah didapatkan kemudian diolah menggunakan software Surfer 11 dan ZondSP. Hal ini dilakukan untuk mendapatkan penampang Isopotensial dan model bawah permukaan Self potential. Metode inversi yang dipakai ialah metode Marquardt yang merupakan fitur dalam software ZondSP. Dilakukannya inversi ini bertujuan untuk mempermudah dalam proses pengolahan dan untuk mendapatkan pendugaan model yang mendekati model sebenarnya. 


\section{HASIL DAN PEMBAHASAN}

Hasil pengolahan data Self potential dan native potential menggunakan Surfer 11 menunjukkan hasil penampang sebagai berikut:

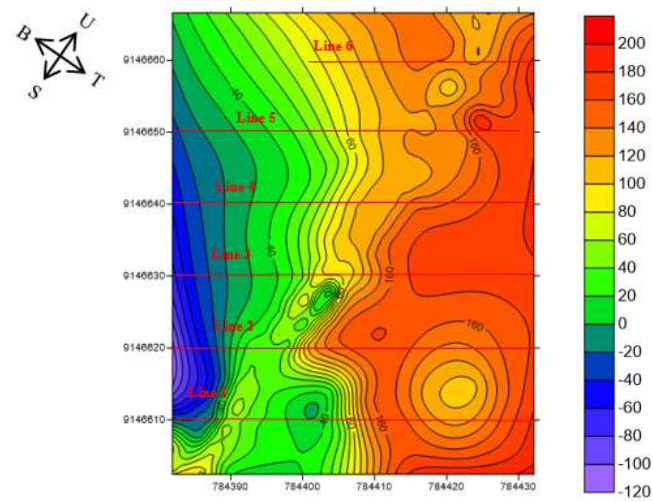

Gambar 3. Penampang Self Potensial (SelatanUtara)

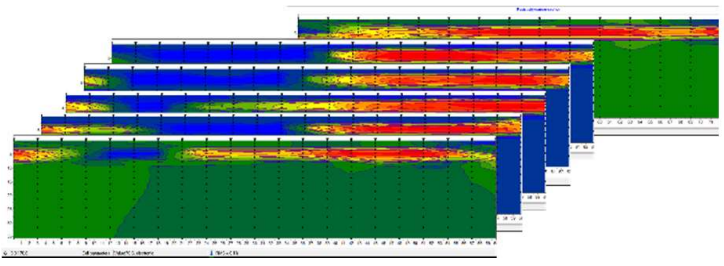

Gambar 4. Cross-plot penampang Self

Potensial line 1-6 (Selatan-Utara)

Pada penampang 1D dari hasil pengolahan surfer diketahui sebaran nilai potensial yang semakin tinggi hingga $\geq 100 \mathrm{mV}$ pada daerah utara (menjauhi base), nilai potensial yang tinggi mengindikasikan background potensialnya berupa kandungan air tanah, akan tetapi karena geologi daerah penelitian berupa tanah urukan yang awalnya berupa laut, maka diindikasikan kandungan air tanahnya berupa intrusi dari air laut. Nilai potensial negative atau $<100 \mathrm{mV}$ pada daerah selatan mengindikasikan adanya arus fluida dibawah permukaan yang dimungkinkan juga berasal dari intrusi air laut dengan intensitas yang sedang yaitu $-120 \mathrm{mV}$ hingga $-1 \mathrm{mV}$ (lihat gambar 3).

Gambar 4 diatas merupakan cross plot model hasil pengolahan ZondSP dengan urutan lintasan 1 berada diposisi paling depan kemudian lintasan 2 dan seterusnya. Dari 6 penampang bisa dilihat beberapa kesamaan, anomali terlihat dikedalaman 2-5 meter dibawah permukaan tanah dengan variasi nilai yang berbeda. Pada sisi selatan, yaitu 131 meter (0 meter $=$ base) nilai potensialnya relatif sedang yaitu $0.2-20 \mathrm{mV}$. Sedangkan pada jarak 3275 meter nilai potensialnya sangat tinggi yaitu $20-$ $500 \mathrm{mV}$.

Perbedaan tingkat potensial ini diindikasi dipengaruhi oleh kandungan air dibawah permukaan tanah. Dugaan mengenai interface air laut ini dilakukan dilokasi yang sama dengan pengambilan data self potential. Dari table 1 diketahui intrusi air laut berada pada kedalaman hingga 4.5 meter dibawah permukaan tanah. Intrusi air laut mempengaruhi kelembaban tanah sehingga mempengaruhi nilai self potential tanah, semakin besar kandungan air dalam tanah maka akan semakin tinggi pula nilai potensialnya.

Tabel 4 1. Dugaan Interface air laut

\begin{tabular}{|c|c|c|c|}
\hline $\begin{array}{c}\text { No } \\
\text { Lintasa } \\
n\end{array}$ & $\begin{array}{c}\text { Jarak } \\
\text { Dalam } \\
\text { Lintasa } \\
\mathrm{n}(\mathrm{m})\end{array}$ & $\begin{array}{c}\text { Kedalama } \\
\mathrm{n} \text { (MSL) }\end{array}$ & $\begin{array}{c}\text { Keteranga } \\
\mathrm{n}\end{array}$ \\
\hline \multirow{4}{*}{1} & $0-45$ & $\begin{array}{c}-2 \text { sampai } \\
0\end{array}$ & \multirow{2}{*}{ Interface } \\
\hline & $45-70$ & $\begin{array}{c}0 \text { sampai - } \\
4.5\end{array}$ & \\
\hline & $0-45$ & $\begin{array}{c}-1 \text { sampai } \\
1.5\end{array}$ & \multirow{2}{*}{ Payau } \\
\hline & $45-70$ & $\begin{array}{c}1.5 \text { sampai } \\
-4\end{array}$ & \\
\hline \multirow[t]{2}{*}{2} & $0-70$ & $\begin{array}{c}0 \text { sampai - } \\
2\end{array}$ & Interface \\
\hline & $0-70$ & 2 sampai 0 & Payau \\
\hline \multirow{2}{*}{3} & $0-34.5$ & $\begin{array}{c}-1 \text { sampai } \\
-0.5\end{array}$ & Interface \\
\hline & $0-34.5$ & $\begin{array}{c}-0.5 \\
\text { sampai } 0\end{array}$ & Payau \\
\hline \multirow[t]{2}{*}{4} & $0-34.5$ & $\begin{array}{c}-0.5 \\
\text { sampai - } \\
1.5\end{array}$ & Interface \\
\hline & $0-34.5$ & $\begin{array}{c}0 \text { sampai - } \\
1\end{array}$ & Payau \\
\hline
\end{tabular}


Dalam penampang self potensial didapat 2 bagian tingkat potensial yang pertama pada sisi selatan lintasan dengan nilai potensial sedang -120 hingga $40 \mathrm{mV}$ pada jarak 1-31 meter dan pada sisi utara dalam jarak 32 sampai 75 meter nilai potensialnya sangat tinggi yaitu 40-220 mV. Perbedaan tingakat potensial ini disebabkan intrusi air laut yang berbeda pada tiap sisi, pada sisi utara berada lebih dekat dengan bibir pantai sehingga tingkat intrusinya paling tinggi dan menyebabkan potensialanya juga tinggi sedangkan pada sisi selatan terletak lebih jauh dari bibir pantai.

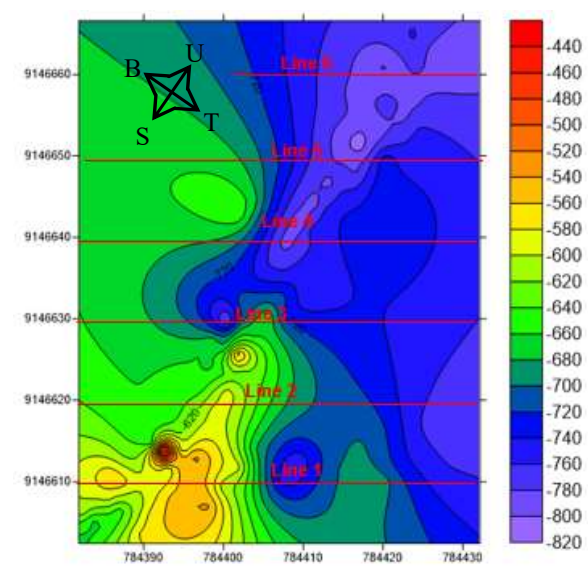

Gambar 5 Penampang Native Potensial

Pada penampang 2D native potential diatas dapat diketahui sebaran native potensial dengan range -600 hingga -820 berada pada sisi utara yang mengindikasi tingkat korosivitas sangat tinggi berbahaya (severe) yaitu <-600 mV. Sedangkan pada sisi tengah penampang nilai native potential berkisar antara -680 hingga -620 yang berarti sangat korosif. Dan pada sisi selatan penampang menunjukkan nilai -600 hingga -480 yang menunjukkan tanah tersebut bersifat korosif sedang.

Nilai self potensial yang didapatkan kemudian dikorelasikan dengan nilai native potensial guna mendapatkan range korosivitas tanah yang selanjutnya digunakan untuk menentukan zona korosivitas. Pada tahap korelasi ini digunakan analisis korelasi dengan perhitungan koefisien korelasi $(R)$ berdasarkan sekumpulan data $(X, Y)$ dimana $X$ dan $Y$ merupakan variable yang akan dikorelasikan. Variable $\mathrm{X}$ berupa data native potensial dan variable $\mathrm{Y}$ berupa data self potensial. Setelah dilakukan perhitungan maka didapatkan nilai koefisien korelasi antara $X$ dan $Y$ sebesar 0.8 yang mengindikasi korelasi yang kuat antara kedua variabel. Dari hasil korelasi diketahui semakin rendah nilai native potensial maka akan semakin tinggi nilai self potensial sehingga dengan nilai potensial yang semakin tinggi tingkat korosivitas tanah juga semakin tinggi (berbanding lurus).

Dari hasil korelasi didapatkan penampang zona korosivitas tanah berdasarkan nilai self potensial secara lateral sebagai berikut:

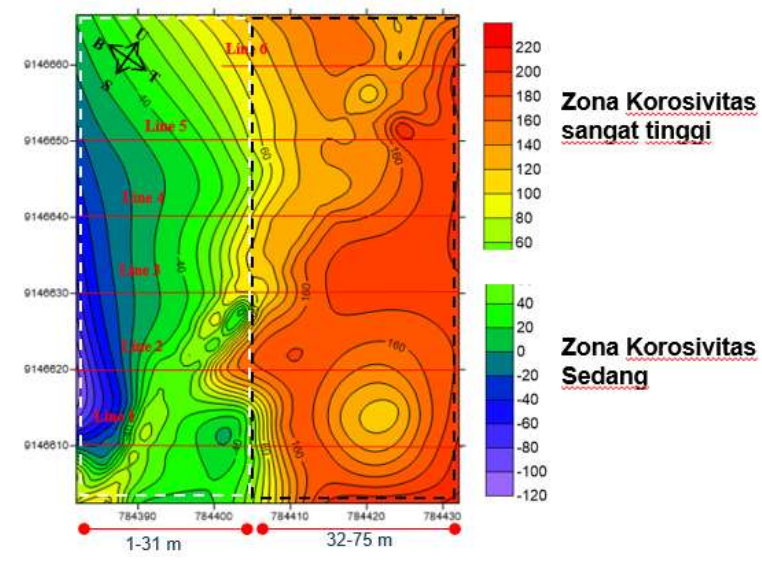

Gambar 6. Penampang zona korosivitas tanah

Dari penampang diatas dapat diketahui zona korosivitas tinggi terletak di bagian utara pada lintasan pengukuran yaitu pada zona yang tingkat intrusinya tinggi. Tingkat korosivitas tanah semakin melemah pada arah selatan yang memiliki nilai self potential rendah.

\begin{tabular}{|c|c|c|c|}
\hline $\begin{array}{c}\text { Tingkat } \\
\text { Korosivitas }\end{array}$ & $\begin{array}{c}\text { Nilai Self } \\
\text { potential }\end{array}$ & $\begin{array}{c}\text { Native } \\
\text { Potential }\end{array}$ & Jarak \\
\hline Sedang & $\begin{array}{c}-120 \text { sampai } \\
40\end{array}$ & $\begin{array}{c}-440 \\
\text { sampai - } \\
640\end{array}$ & $1-31 \mathrm{~m}$ \\
\hline $\begin{array}{c}\text { Sangat } \\
\text { tinggi }\end{array}$ & $\begin{array}{c}4 \text { sampai } \\
220\end{array}$ & $\begin{array}{c}-640 \\
\text { sampai - } \\
820\end{array}$ & $\begin{array}{c}32- \\
75 \mathrm{~m}\end{array}$ \\
\hline
\end{tabular}




\section{SARAN}

Penelitian ini dapat digunakan sebagai survey awal dalam peletakan pipa bawah permukaan serta penentuan protekti pada pipa dan perlu diperhatikan kondisi cuaca dan kondisi tanah yang akan diukur, tanah akan terukur dengan baik pada saat kering.

\section{UCAPAN TERIMA KASIH}

Penulis menggucapkan terimakasih kepada Dr. Widya Utama, DEA dan Juan Pandu GNR S.Si, M.T selaku pembimbing yang telah meluangkan banyak waktu untuk memberikan bimbingan dan arahan kepada penulis, tim Korosi yang selalu membantu dalam kelancaran penelitian. Serta seluruh dosen dan staf Departemen Teknik Geofisika ITS yang banyak memberikan ilmu dan membantu secara administrasi selama penulis melakukan studi di Departemen Teknik Geofisika ITS.

\section{DAFTAR PUSTAKA}

Beavers, J.A., Thompson, N.G. 2006. External Corrosion of Oil and Natural Gas Pipeline. ASM Handbook Volume 13C, Corrosion: Environments and Industries. ASM International.

Kiswara, Reza, 2009. Pengaruh resistivitas tanah terhadap Pengukuran potensial baja dengan multimeter Digital dan mikrokontroler atmega8353.

Pendowo., H. Samodera., 1997, Peta Geologi Lembar Besuki Jawa Timur, Skala 1 : 100.000, Pusat Penelitian dan Pengembangan Geologi, Bandung.

Reynold, John M. 1997. An Introduction to Applied and Environmental Geophysics. West Sussex: Wiley.

Steel pipe Native Potentials in Soil Affect CP Criteria, March 2012, Vol 239 No 3)

Taufiqurrohman, Rizal. 2017. Pendugaan Zona Intrusi Air Laut Dan Pengaruh Terhadap Zona Korosi Lokal Tanah Berdasarkan Nilai Resistivitas Tanah Dengan Menggunakan
Metode Resistivitas 2d. Surabaya. Institut Teknologi Sepuluh Nopember

Telford, W. M. 1990. Applied Geophysics Second Edition. USA: Cambridge University Press

Usman, H. dan R. Purnomo Setiady Akbar. 2000. Pengantar Statistika. Jakarta : Bumi Aksara. 